\title{
Acacia mearnsii Invasion on Soil Microbial Population of Shola Forests in the Western Ghats
}

\author{
A. C. Surya Prabha ${ }^{1 *}$, K. Arulmani ${ }^{1}$, M. Senthivelu ${ }^{2}$, R. Velumani $^{1}$ and S. Padmini ${ }^{1}$ \\ ${ }^{1}$ Silviculture and Forest Management Division, Institute of Forest Genetics and Tree \\ Breeding, Coimbatore-641 002, Tamil Nadu, India \\ ${ }^{2}$ Maize Research Station, Vagarai, Tamil Nadu Agricultural University, India \\ *Corresponding author
}

\section{A B S T R A C T}

\section{Keywords}

Soil microbes, Acacia mearnsii, Shola forest

Article Info

Accepted:

26 July 2020

Available Online:

10 August 2020
The Australian Black Wattle (A. mearnsii), an invasive alien species introduced in the upper altitudes of the Palani hills threatens the high altitude ecosystem The present investigation was undertaken to study the soil microbial population in shola forests invaded by $A$. mearnsii plantations in the Western Ghats covering the Kodaikanal. Soil samples were collected from shola forests invaded by A. mearnsii in three forest ranges viz, Kodaikanal, Berijam and Poombarai of the Kodaikanal Forest Division. For comparison purpose, soil samples were collected from shola forest, pure A. mearnsii plantation, grass land and pine plantations. The study showed a significant variation in the microbial population in the different study plots with the highest bacterial $\left(29.3 \times 10^{8} \mathrm{cfu} \mathrm{g}^{-}\right.$ $\left.{ }^{1}\right)$, fungal $\left(15.0 \times 10^{4} \mathrm{cfu} \mathrm{g}^{-1}\right)$ and actinomycetes $\left(3.0 \times 10^{3} \mathrm{cfu} \mathrm{g}^{-1}\right)$ population in shola forest in all the three ranges of Kodaikanal Forest Division. The population of soil microbes in Berijam and Poombarai forest range was also high under shola forests. This study has contributed to the understanding of soil microbial population in A. mearnsii invaded shola forests.

\section{Introduction}

Tropical Montane, evergreen forests locally known as sholas, situated in the higher mountain tracts of the Western Ghats, at an altitude above $1500 \mathrm{~m}$ is interspersed with rolling grasslands. Sholas stay in restricted boundaries, in small pockets and the grasslands dominate. These bio diverse forests and grasslands were converted into commercially valuable plantation to serve fuel wood need of tea industry during British period. Some of the introduced species like $A$. mearnsii have become invasive alien species in this ecosystem and became a serious threat to this high altitude ecosystem (Myers et al., 2000).

The Australian Black Wattle (A. mearnsii) was introduced during the 1960s in State Forest lands located in the upper altitudes of the Palani hills - an eastern offshoot of the Western Ghats, a mountain range that runs parallel to the southwest coast of Peninsular India near the hill station of Kodaikanal (Mitchell, 1972; Mathew et al., 1975). The 
tree species is well established in the upper Palani hills between 1800 and 2400m both within State Forest plantations and in areas near towns and rural settlements (Rangan et al., 2010). Mass of leaf litter in areas invaded by $A$. mearnsii was reported to be greater than that of un-invaded area, thereby the dense layer inhibits the establishment of native seedlings. Between 1849 and 1992, the sholas decreased from 8600ha to 4225 ha and grasslands from 29875 ha to 4700 ha. This non-regenerating and fast-receding shola forest is a dying community, more appropriately called a 'living fossil' community. Soil microbial communities have important role in organic matter decomposition, nutrient cycling, soil structural formation, and even plant interactions (Wardle et al., 2004). The abundance, size and activity of the microbial populations depend on the quantity and quality of organic matter, texture and other environmental factors (Insam et al., 1989; Kaiser et al., 1992) as well as limited carbon content (Lynch and Whipps, 1990; Wardle, 1992). Soil biological health is also an important indicator of soil quality. Soil microbial communities are extremely diverse in their composition and play an important role in nutrient cycling functions such as organic matter decomposition and mineralization, nutrient mobilization and carbon sequestration (Strickland and Rousk, 2010).

Studies on the soil microbial properties in invaded shola forests are required for proper management of the forests and utilization of resources. Comparative studies on the assessment of soil microbes under shola forests invaded by A. mearnsii in the Western Ghats of Kodaikanal are sparse. Hence, the present study was proposed with an aim to study the soil microbial population of shola forests invaded by $A$. mearnsii plantations in the Western Ghats.

\section{Materials and Methods}

The present study was carried out in the Western Ghats of Tamil Nadu covering three forest ranges of the Kodaikanal Forest Division viz, Kodaikanal, Berijam and Poombarai. Kodaikanal Forest Division lies within $10^{\circ} 6^{\prime}$ and $10^{\circ} 21^{\prime}$ North latitudes and $77^{\circ} 16^{\prime}$ and $77^{\circ} 42^{\prime}$ East longitudes and is surrounded by Kerala state in West, Indira Gandhi Wild life sanctuary, Pollachi in Northwest, Dindigul forest division on the Northeast and Theni revenue district in South. The altitude varies from 300 to $2654 \mathrm{~m}$ and this area experiences an average yearly rainfall of $165 \mathrm{~cm}$. The minimum temperature of Kodaikanal varies between 8 to $13{ }^{\circ} \mathrm{C}$ and the maximum temperature varies between 11.3 to $19.8{ }^{\circ} \mathrm{C}$.

\section{Enumeration of microorganisms from soil by the serial dilution-agar plating method (or viable plate count method)}

Soil samples were collected from the rhizosphere at a depth of $0-20 \mathrm{~cm}$ layer of the top soil. Three replicate soil samples were collected from the selected plots of the shola forests invaded by $A$. mearnsii in the three forest ranges of Kodaikanal Forest Division viz, Kodaikanal Forest Range, Berijam Forest Range and Poombarai Forest Range. For comparison purpose, soil samples were also collected from shola forest, pure A. mearnsii plantation, grass land and pine plantations. Enumeration of Microorganisms (bacteria, fungus and actinomycetes) was carried out by standard serial dilution plate technique (Waksman, 1922). About 10 grams of soil was transferred to $90 \mathrm{ml}$ sterile distilled water and agitated vigorously. Different aqueous dilutions, up to $10^{-9}$ of the suspensions were prepared and spread plated on soybean casein digest medium for bacteria and fungus and actinomycetes isolation agar for enumeration of actinomycetes. Inoculated plates were 
incubated at $37^{\circ} \mathrm{C}$ for $24-44 \mathrm{hrs}$. After incubation microbial colonies were counted and the load was expressed as number of colony forming units (CFU) per gram of soil.

No. of cells $/ g=$ Number of colonies $\times$ dilution factor

Dry wt. of soil

All statistical tests were performed with SPSS (B) 19.0 version statistical software. Wherever the treatment differences were found significant, the critical differences were worked out at 5 per cent probability and values were furnished. The treatment differences that are non-significant were indicated as Non-Significant (NS).

\section{Results and Discussion}

\section{Microbial population in Kodaikanal range}

Soil samples for microbial enumeration were collected from the different study plots and the population of microbes was expressed as colony forming units (cfu) per gram of soil. The microbial population varied significantly among the study plots (Table 1). The bacterial population ranged from $12.8 \times 10^{8}$ to $29.3 \times 10^{8}$ $\mathrm{cfu} \mathrm{g}^{-1}$. Among the different study plots, shola forest recorded the highest bacterial population $\left(29.3 \times 10^{8} \mathrm{cfu} \mathrm{g}^{-1}\right)$ followed by $A$. mearnsii invaded shola $\left(21.6 \times 10^{8} \mathrm{cfu}^{-1}\right)$. The lowest population of bacteria was recorded in pine forest $\left(12.8 \times 10^{8} \mathrm{cfu} \mathrm{g}^{-1}\right)$. The fungal population was highest in shola forests $\left(15.0 \times 10^{4} \mathrm{cfu} \mathrm{g}^{-1}\right)$ and the lowest in grassland $\left(7.8 \times 10^{5} \mathrm{cfu} \mathrm{g}^{-1}\right)$ (Fig.18). With respect to actinomycetes population, shola forest had the highest population $\left(3.0 \times 10^{3} \mathrm{cfu} \mathrm{g}^{-1}\right)$ and it was lowest in pine forest.

The present study showed a significant variation with regard to the microbial population in the different study plots with the highest bacterial, fungal and actinomycetes population in shola forest of the Kodaikanal range. This variation in microbial population in soil can be ascribed to the difference in micro- and macro-climatic and edaphic factors prevalent at each site, which are known to influence the microbe population (Sankaran and Balasundaran, 2001).

\section{Microbial population in Berijam range}

In the Berijam range, the bacterial population ranged from $10.7 \times 10^{6}$ to $28.8 \times 10^{8} \mathrm{cfu} \mathrm{g}^{-1}$ (Table 2). Among the different study plots, shola forest recorded the highest bacterial population $\left(28.8 \times 10^{8} \mathrm{cfu} \mathrm{g}^{-1}\right)$ followed by $A$. mearnsii invaded shola $\left(21.6 \times 10^{8} \mathrm{cfu} \mathrm{g}^{-1}\right)$ and A. mearnsii plantation $\left(16.3 \times 10^{8}\right)$. Pine forest registered the lowest population of bacteria $\left(10.7 \times 10^{6} \mathrm{cfu} \mathrm{g}^{-1}\right)$. With respect to the fungal population, shola forests had the highest fungal load $\left(16.3 \times 10^{4} \mathrm{cfu} \mathrm{g}^{-1}\right)$ and the lowest in grassland $\left(9.1 \times 10^{5} \mathrm{cfu} \mathrm{g}^{-1}\right)$.

Table.1 Microbial population under different study plots in Kodaikanal range

\begin{tabular}{|l|c|c|c|}
\hline \multicolumn{1}{|c|}{ Study plots } & $\begin{array}{c}\text { Bacteria } \\
\left(\mathbf{c f u ~ g}^{-\mathbf{1}}\right)\end{array}$ & $\begin{array}{c}\text { Fungi } \\
\left(\mathbf{c f u ~ g}^{-1}\right)\end{array}$ & $\begin{array}{c}\text { Actinomycetes } \\
\left(\mathbf{c f u ~ g}^{-\mathbf{1}}\right)\end{array}$ \\
\hline A. mearnsii invaded shola & $21.6 \times 10^{8}$ & $13.6 \times 10^{4}$ & $2.6 \times 10^{3}$ \\
\hline A. mearnsii plantation & $15.5 \times 10^{6}$ & $12.5 \times 10^{5}$ & $2.1 \times 10^{3}$ \\
\hline Grassland & $14.1 \times 10^{8}$ & $7.8 \times 10^{5}$ & $1.6 \times 10^{3}$ \\
\hline Pine forest & $12.8 \times 10^{8}$ & $8.6 \times 10^{4}$ & $1.4 \times 10^{3}$ \\
\hline Shola forest & $29.3 \times 10^{8}$ & $15.0 \times 10^{4}$ & $3.0 \times 10^{3}$ \\
\hline \multicolumn{1}{|c|}{ SE(d) } & 0.77 & 0.53 & 0.10 \\
\hline CD $(\mathbf{0 . 0 5})$ & 1.68 & 1.16 & 0.21 \\
\hline
\end{tabular}


Table.2 Microbial population under different study plots in Berijam range

\begin{tabular}{|c|c|c|c|}
\hline Study plots & $\begin{array}{c}\text { Bacteria } \\
\left(\text { cfu g }^{-1}\right)\end{array}$ & $\begin{array}{l}\text { Fungi } \\
\left(\text { cfu g }^{-1}\right)\end{array}$ & $\begin{array}{l}\text { Actinomycetes } \\
\left(\text { cfu g }^{-1}\right)\end{array}$ \\
\hline A. mearnsii invaded shola & $24.4 \times 10^{8}$ & $15.2 \times 10^{4}$ & $3.8 \times 10^{3}$ \\
\hline A. mearnsii plantation & $16.3 \times 10^{8}$ & $12.0 \times 10^{4}$ & $2.6 \times 10^{3}$ \\
\hline Grassland & $14.4 \times 10^{8}$ & $11.6 \times 10^{5}$ & $1.4 \times 10^{3}$ \\
\hline Pine forest & $10.7 \times 10^{6}$ & $9.1 \times 10^{5}$ & $2.3 \times 10^{3}$ \\
\hline Shola forest & $28.8 \times 10^{8}$ & $16.3 \times 10^{4}$ & $5.6 \times 10^{3}$ \\
\hline SE(d) & 0.85 & 0.61 & 0.14 \\
\hline CD $(0.05)$ & 1.85 & 1.32 & 0.30 \\
\hline
\end{tabular}

Fig.1 A. mearnsii invasion on soil microbial population (cfu/g) in Poombarai range

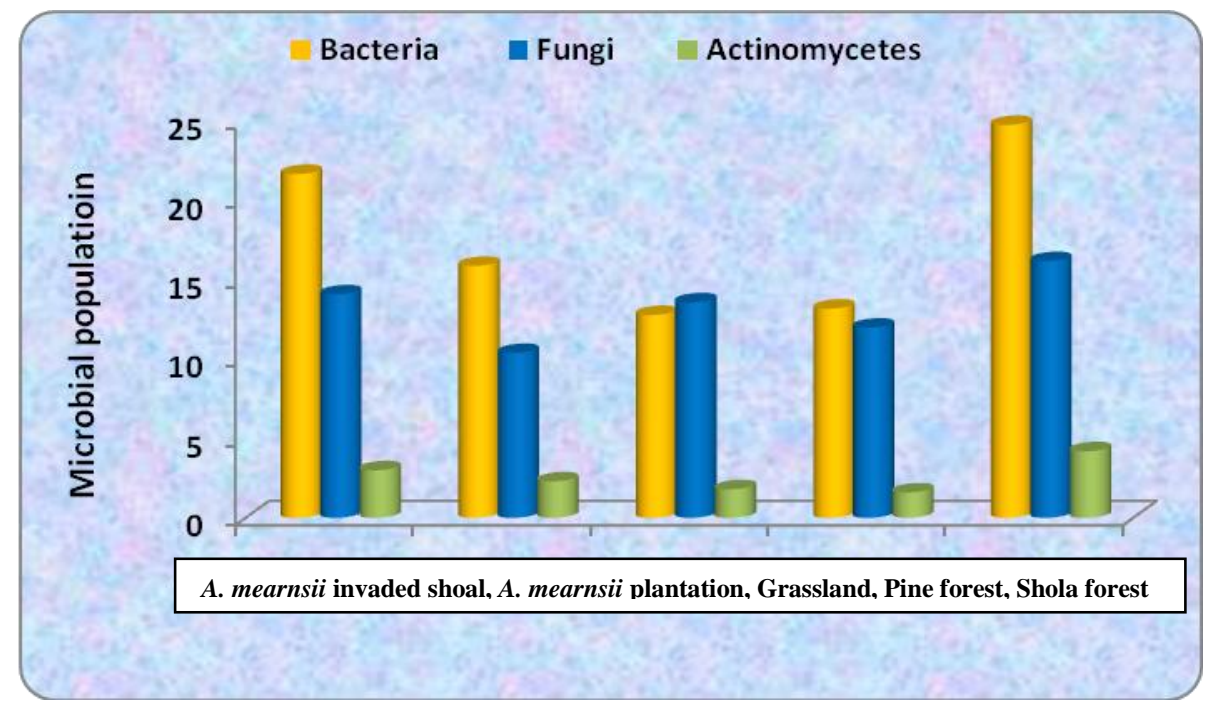

The actinomycetes population was highest in shola forest $\left(5.6 \times 10^{3} \mathrm{cfu}^{-1}\right)$ and it was lowest in grassland. Silva et al., (2005) reported that microbial population were significantly greater in forest soil than in field soil, which could also be related to the higher level of soil organic matter in the forest soil. The present study also revealed higher bacterial, fungal and actinomycetes population in shola forest of the Berijam range.

\section{Microbial population in Poombarai range}

The bacterial population in Poombarai range varied from $12.8 \times 10^{8}$ to $24.8 \times 10^{8} \mathrm{cfu} \mathrm{g}^{-1}$. The population of bacteria was highest under shola forest $\left(24.8 \times 10^{8} \mathrm{cfu} \mathrm{g}^{-1}\right)$ and lowest in grassland (Fig.1). The fungal population was highest in shola forests $\left(16.2 \times 10^{4} \mathrm{cfu} \mathrm{g}^{-1}\right)$ and the lowest in $A$. mearnsii plantation (10.4 $\mathrm{x} 10^{5} \mathrm{cfu}^{-1}$ ). With respect to actinomycetes population, shola forest had the highest population $\left(4.2 \times 10^{3} \mathrm{cfu} \mathrm{g}^{-1}\right)$ and it was lowest in pine forest $\left(1.6 \times 10^{3} \mathrm{cfu} \mathrm{g}^{-1}\right)$. As shown earlier, this higher number of microbial population in shola forest might be because of symbiotic relation of microorganism with tree species and microclimate developed in rhizosphere (root soil) soil by tree species (Sharma et al., 2009; Golinska and Dahm, 2011).

The study has enabled generation of baseline data on the soil microbial population in the shola forests invaded by Acacia mearnsii in 
Kodaikanal, Berijam and Poombarai ranges of the Kodaikanal Forest Division.

\section{Acknowledgement}

We are thankful to Director General, Indian Council of Forestry Research and Education, Dehradun for providing financial support to undertake the project work.

\section{References}

Golinska, P. and Dahm, H. 2011. Occurrence of actinomycetes in forest soil. Dendrobiology, 66: 3-13.

Insam, H., Parkinson, D. and Domsch, K.H. 1989. Influence of macroclimate on soil microbial biomass. Soil Biology and Biochemistry, 21:211-221.

Kaiser, E.A., Mueller, T., Joergensen, R.G., Insam, H. and Heinemeyer, O. 1992. Evaluation of methods to estimate the soil microbial biomass and the relationships with soil texture and organic matter. Soil Biology and Biochemistry, 24: 675-683.

Lynch JM and Whipps JM (1990) Substrate flow in the rhizosphere. Plant and Soil, 129, 1-10.

Matthew, K.M., Blasco, F., Ignacimuthu, S.1975. Biological changes at Kodaikanal, 1949-1954.

Mitchell, N.1972. The Indian hill-station: Kodaikanal. University of Chicago Department of Geography Research, Paper No.141, University of Chicago, Chicago.

Myers, N., Mittermeier, R.A., Mittermeier, C.G,

Da Fonseca, G.A. B. and Kent, J. 2000. Nature, 403: 853-858.

Rangan, H., C. A. Kull, and L. Alexander.
2010. Forest plantations, water availability, and regional climate change: controversies surrounding A. mearnsii plantations in the upper Palni Hills, southern India. Regional Environmental Change, 10 (2): 103-117.

Sankaran, K.V. and Balasundaran, M. 2001. Soil microflora of the shoals of Eravikulam national park, Idukki district. In: Shola forests of Kerala: Environment and biodiversity. Eds. K.K.N.Nair, S.K. Khanduri and K. Balasubramanyan. Pp. 151-178.

Sharma, B.K., Sarma, H.K., Shukla, A.K., and Tiwari, S.C. 2009. Impact of seabuckthorn stands on rhizospheric and soil microbial population. Indian Journal of Forestry, 32(2): 263-268.

Silva, R.G., Jorgensen, E.E., Holub, S.M., and Gonsoulin, M.E. 2005. Relationships between culturable soil microbial populations and gross nitrogen transformation processes in a clay loam soil across ecosystems. Nutrient Cycling in Agroecosystems, 71(3): 259-270.

Strickland, M.S. and Rousk, J. 2010. Considering fungal: bacterial dominance in soils methods controls, and ecosystem implications. Soil Biology and Biochemistry, 42:1385-1395.

Waksman, S.A. 1922. A method for counting the number of fungi in the soil. Journal of Bacteriology, 1385-1395.

Wardle, D. A., L. R. Walker, and R. D. Bardgett. 2004. Ecosystem properties and forest decline in contrasting longterm chronosequences. Science, 305:509-513.

Wardle, D.A. 1992. A comparative assessment of factors which influence microbial biomass carbon and nitrogen levels in soil. Biological Reviews, 67:321-335.

\section{How to cite this article:}

Surya Prabha, A. C., K. Arulmani, M. Senthivelu, R. Velumani and Padmini, S. 2020. Acacia mearnsii Invasion on Soil Microbial Population of Shola Forests in the Western Ghats. Int.J.Curr.Microbiol.App.Sci. 9(08): 3421-3425. doi: https://doi.org/10.20546/ijcmas.2020.908.395 